\title{
AN ANALYSIS OF ILLOCUTIONARY AND PERLOCUTIONARY SPEECH ACTS OF AN INSTAGRAM ONLINE SHOPPING ACCOUNT
}

\author{
Cahya Wati Dewi ${ }^{1}$ \\ ${ }^{1}$ IKIP Siliwangi \\ ${ }^{1}$ cahyawatidewi@student.ikipsiliwangi.ac.id
}

\begin{abstract}
Language is important in human's life because we cannot communicate with one another without it. Therefore, it is appealing to study speech acts since we can understand how utterances are reflected in actions. It is also interesting to analyze the speech acts used in Instagram captions. This study aims to analyze speech acts of an online shopping account on Instagram that is an international brand N.Y.X. Illocutionary speech acts aims to state something to influence the listener to do activities according to what the speaker means. Based on the data obtained, the illocutionary act of the online shopping account @ nyxcosmetics is in the form of directive and expressive acts. The directives illocution acts are ordering and demanding. On the other hand, the perlocutionary aims to portray the act of offering someone.
\end{abstract}

Keywords: Speech Acts, Illocutionary Acts, Perlocutionary Acts

\section{INTRODUCTION}

On daily communications, language carries out an important role. When people practice language, they can express what they have in mind. However, when people communicate with one another, sometimes one does not understand what the other speaker means, or the speaker's meaning sounds absurd. Therefore, this research aims to analyze what the speaker means. This research demonstrates how language is adopted by the user in pragmatics. Pragmatics is a study about the meaning of a speaker's speech. Pragmatics is also about the relationship between linguistics forms and the users of those forms (Zulfa, 2018). Thus, pragmatics is not only studying linguistics forms but equally considering the speaker's meaning and context. Pragmatics is a part of linguistics that study the meaning of a context in a speech. According to Yule "pragmatics is a study about the speaker's meaning, contextual meaning, and what more to get communicated than what the speaker has stated; and the study of the relation of relative distance" (Tutuarima, Nuraeningsih, \& Rusiana, 2018).

The focus of Pragmatics is on the speaker's meaning based on the context and the situation. In this research, the researchers focus on speech acts, especially in illocutionary acts. J. L. Austin is the first person who introduces the theory of speech acts (Tutuarima et al., 2018). The Speech act exists in our daily activity, and it has been practised to makeonversations among people. Speech act theory was foreshadowed by Austin views on how to do things with words (Huang, 2007). Afterward, Austin's ideas were refined, systemized, and advanced especially by Searle. Searle's view of speech act theory described it as stating one sentence that is part of the framework of a socially agreed institution and convention. Based on Searle's view, this research conducted an analysis of illocutionary and perlocutionary speech acts of an online shopping account on Instagram. In fact, Instagram account has a broad appealing as a social media. 


\section{Pragmatics on Social Media}

There are many social media users who use Instagram accounts as a tool of building communications. The interesting fact of Instagram is that it is not only as a communication tool but also it can be used as a promotion media. Instagram has features that can help users to communicate with one another, including captions, comments and personal messages. Actually, Instagram users take advantage of these features to perform branding on their products or services. Based on the phenomenon above, the researchers, thus, were interested to do speech act analysis on the Instagram users' captions since captions describe performative language. When speaking, individuals not only mention one sentence that has a grammatical structure and words, but also carry out activities when they speak.

Speech acts are thus also to be distinguished from performatives. 'Performative' is another technical term; it refers to the first instance of a sentence. A performative sentence is in the first person, present tense, indicative mood, active voice, that describes its speaker as performing a speech act. We may also define a performative utterance as an utterance of a performative sentence that is also a speech act (Green, 2017). Language is important in our life because without language we cannot communicate with other people.

According to Huang (2007) one of the understanding or principles of logical positivism is descriptive fallacy, an opinion that assumes that the function of language from a philosophical point of view is to create statements that are true or false (Huang, 2007). On such a view, sentences that are used by the Instagram users for branding are simply meaningless because they are not used to verify or falsify propositions. Data of speech acts were found on the Instagram captions according to the theory of speech act by Austin (1955).

Austin has produced two important studies. Firstly, that some common sentences are not used to make statements, and therefore, it is not mentioned whether the sentence is true or false. Secondly, there are decralative sentences which are also important to note, which reject the conditional truth analysis in the same way.

\section{Illocutionary and Perlocutionary Acts}

In this study, illocutionary and perlocutionary acts are interesting to analyze. Utterance can be used to do something besides its functions to say or inform something. Thus, if that happens, then the speech act on the speech is illocutionary. Illocutionary acts are also referred to as "the act of doing something." Based on the description, the researchers found an illocutionary act utterance on the online shopping account of Instagram. Furthermore, the researchers also discovered data phenomena in the form of acts of perlocution arising from the speech. Therefore, it is interesting to study speech act because we can know how the utterances are reflected in actions. It is also interesting to analyze the speech act used in social media. Many people use social media to build communication or market share. This study analyzes how to use speech acts on captions of an instagram online shopping account.

\section{METHOD}

This research used a qualitative approach. A qualitative approach aims to build a knowledge statement based on a constructive or perspective participatory (Budiasih, 2016). This study intends to do an analysis of speech acts of an online shopping account on an international brand N.Y.X cosmetics Instagram. Primary data were collected in the following steps: 1) collecting the contents of N.Y.X cosmetics Instagram on March, 2) making the data korpus. A validity of 
the data (content analysis) is a guarantee of stability summary and interpretations of meanings as a result of research.

\section{RESULTS AND DISCUSSION}

\section{Results}

Austin defined the speech act as actions that we perform when we produce utterances like; giving suggestion, promising, inviting, requesting, forbidding, and so on (Sumarsono, 2017). Speech act is utterances which can be categorized into three types i.e. locutionary act, illocutionary act, and perlocutionary act (Fala \& Kumala, 2018). In this section, the researchers only analyzed illocutionary act and perlocutinary act. The reason was that the utterances which were found in instagram online shopping have meanings on illocutionary act and perlocutionary act. Based on the data above, the researchers concluded that speech act is a statement that contains action as a functional unity in communications considering situation aspect. According to Austin (1955) speech act can be categorized into three types (Fala \& Kumala, 2018):

a) Illocutionary Act

The illocutionary act is the process of making statements, offerings, and promises through utterances according to conventional aspects relating either explicitly or performatively. This Act is also interpreted as taking an action to convey a purpose. For example: "It close to seven o'clock". This sentence is uttered by a husband to his wife in the morning. He not only says the words but also reminds his wife that he has to go to his office in that moment. The Illocutionary Act is one of the Speech Acts which helps people do something while saying words.

b) Perlocutinary Act

The perlocutionary act is the impact of the words conveyed by the speaker to the listener. These types of acts are words that can affect others. For example: "There is a snake next to you!", if we say this utterance to someone, there will be some effects caused by that utterance. If the hearer heard that utterance, he/she might run.

Based on the data, the researchers identified utterances into five kinds of function according to Searle's classification. The majority of the data are identified as the 1) assertive, 2) directive, 3) declarative, 4) commissive, and 5) expressive.

\section{Discussion}

The following is the descriptions of data put on online shopping account on international brand N.Y.X Instagram:

\section{a. Illocutionary Act}

\section{1) Directive}

Directive is the type of speech act that aims to get listener to do something (Sembiring \& Ambalegin, 2019). The functions of directive acts is commanding, requesting, inviting, forbidding, and suggesting. The types of directive as explained above can be seen from the data below:

Data 1

Post ( March 2020)

caption:

nyxcosmetics: what are your tips and tricks to make your shadow POP?! @kimcreates_uses our \#JumboEyeShadow pencil in 'Milk'\#nyxcosmeics \#nyxprofessionalmakeup

comment: 
@ corpse.garden: I used either Analogos or Complimentary color schemes. I love the liquid eyeshadow, it blends really well.

@ rabianunesxox: Stunning eye makeup

@ thivibeauty: Soooo pretty

The utterances were taken from nyxcosmetics Instagram. These utterances show that the admin of nyxcosmetics did a directive illocutinary act that are advising, demanding and ordering. The utterances on the captions that describe meaning of demanding were on a sentence like what are your tips and tricks to make your shadow POP?!. The utterances also portray a meaning of advising on a sentence like @ kimcreates_uses our \#JumboEyeShadow pencil in 'Milk'\#nyxcosmeics. So, the captions show the sentences to invite followers of @nyxcosmetics like \#JumboEyeShadow pencil in 'Milk'\#nyxcosmeics. Furthermore, directive illocutionary act that has ordering meaning is shown on a sentence like uses our \#JumboEyeShadow pencil in 'Milk'\#nyxcosmeics.

Data 2

Post ( March 2020)

caption:

nyxcosmetics: @anggelzz applies our Jumbo Eye Pencil in 'Milk' as a base for this poppin' pastel \#EOTD \#nyxcosmetics \#nxprofessionalmakep

comment:

@ r.m.s.k.h: I love this shade

@anggelss: the best

@ kimgoodyear37: love your lip color, what is it?

The utterances were taken from nyxcosmetics Instagram. These utterances show that the admin of nyxcosmetics did a directive illocutionary act that is ordering. It shows utterances on captions that has meaning that one of the followers @nyxcosmetics uses their product. Furthemore, the utterance has meaning that other followers were ordering @ nyxcosmetics as their product.

Data 3

Post ( March 2020)

caption:

nyxcosmetics: @makeupbyevva applies our best selling \#epicInkLiner as a base for this \#flawless lilac liner.

comment:

@ makeuped_._: so pretty omg

@ anggelss: beautiful makeup love this purple shades

The utterances were taken from nyxcosmetics Instagram. These utterances show that the admin of nyxcosmetics did a directive illocutionary act that is ordering. It shows utterances on captions that has meaning that one of the followers of @ nyxcosmetics uses their product. Furthemore, the utterance that has meanings that other followers to order @ nyxcosmetics as their product.

2) Expressive 
Searle proposed the types of expressive are apologizing, thanking, congratulating, condoling, deploring and welcoming (Sembiring and Ambeligin, 2019). Expressive illocutionary act found in the caption of an online shopping account on @ nyxcosmetics.

Data 4

Post ( March 2020)

caption:

nyxcosmetics: Nothing is more satisfying than applying the perfect lippie @ mellowyellowpay wears our new \#shoutloud Satin Lipsstick in Desert Rose. Which lippie takes your day from 0-100 real wuick?

comment:

@ brookesmakeup444: O pretty in pink

@ michelle_m_kff: beautiful girl and make up

The speech act contains expressive illocution. The caption like Nothing is more satisfying than applying the perfect lippie shows expressive utterance. The speaker explained how pretty and perfect lippie looks. The utterances were taken from nyxcosmetics Instagram. Those utterances show that the admin of nyxcosmetics did an expressive illocutionary act that is advising their followers.

Data 5

Post ( March 2020)

caption:

nyxcosmetics: Liner on point achieve fire line every single time with our bes-selling \#EpicInkLiner

comment:

@ blakk.mua: best luber eeever

@ luv4kai: best liner ever!!! onl one I use

The utterances were taken from nyxcosmetics Instagram. These utterances show that the admin of nyxcosmetics did an expressive illocutionary act that is to command their followers to use their product. It can be can be seen from the follower's comment like @ blakk.mua: best luber eeever @luv4kai: best liner ever!!! onl one I use. That comment shows expressive utterance.

\section{b. Perlocutionary Act}

The perlocutionary act is the effect caused by some utterances that are uttered by the speaker to the listener. It can be said that this act is the act of affecting someone (Fala et al., 2019). A perlocutionary act is an act that is carried out by saying one sentence in a specific context. This Act represents the changes that occur each in that context. This Act is an additional output from the act of communication, explaining something, encouraging someone to be angry, making others entertained, etc. This Act shows words that are not supplemented by special impacts or purposes. (Fala et al., 2019).

Data 6

Post ( March 2020)

caption: 
She's backkkk mark your calenders, beuties. The final Restock of our limited edition. @ sabrinanetflix collection will be wednesday 3/18. Available exclusively on nyxcosmetics.com

\author{
comment: \\ @ tatusmakeup: Ok I nedd this \\ @ nolwee_legoff: I want it but I live in France
}

The data (6), it appears that the speech on the nyxcosmetics instagram caption is a a perlocutinary act. This is identified by the intention of the speaker to give effect or influence. So, in the comment section of other speakers, it gives effect to the other speakers. The effect is that the followers of nyxcosmetics give positive respons. This act is the act of affecting someone.

Data 7

Post ( March 2020)

caption:

Help us \#shoutloud b tagging a beaut who inspire you!

comment:

@juspaid_:Aloha wahines's

@ traganellabialderosyxmac: Hello nyx in Argentina please, I love the brand.

@wendigobeauty: \#shoutlod to @ kenadrogan one of the best friends I've ever had and to @shannoxo $m$ favorite youtuber and the woman I go to before buing any higher end products.

The data (7) is also a form of a perlocutionary act, in which the speech of the speaker has an influence on the listener to shout their opinions. For example, Help us \#shoutloud b tagging a beaut who inspire you! and the hearer answer@juspaid_: Aloha wahines's, @traganellabialderosyxmac: Hello nyx in Argentina please, I love the brand., @wendigobeauty: \#shoutlod to @ kenadrogan one of the best friends I've ever had and to @ shannoxo $m$ favorite youtuber and the woman I go to before buing any higher end products.

\title{
CONCLUSION
}

The illocutionary speech act aims to state something in order to influence the listener to do something according to what the speaker means. It is found that the illocutionary act on online shopping of @ nyxcosmetics Instagram account is the form of acts of directive and expressive. The directive illocution data are ordering and demanding. On the contrary, the perlocutionary speech act aims to affect someone.

\section{ACKNOWLEDGMENTS}

Alhamdulillah, thank you Allah, my family, my lecturer and those who have supported this research.

\section{REFERENCES}

Austin, J. L. (1955). How To Do Things With Words. London: Oxford University Press. 
Fala, A., Intan, K., Z, T., W. A, S., U.A, D., \& N, W. (2019). An Analysis of Speech Acts in the Croods Movie, 7(1), 277-284. https://doi.org/https://doi.org/10.22216/jk.v3i1.3161

Fala, A., \& Kumala, I. (2018). An Analysis of Speech Acts in the Croods Movie. Kumala /Academic J Edu. Sci, 1(1), 1-7. https://doi.org/10.22341/ajes.00101p001

Green, M. (2017). Speech Acts (Stanford Encyclopedia of Philosophy). (E. N. Zalta, Ed.) (Winter 201). Retrieved from https://plato.stanford.edu/entries/speech-acts/\#Int

Huang, Y. (2007). Pragmatics. New York: Oxford Universit Press.

Sembiring, W. A., \& Ambalegin, A. (2019). Illocutionary Acts on Aladdin Movie 2019. JURNAL BASIS, 6(2), 277-284. https://doi.org/10.33884/basisupb.v6i2.1419

Sumarsono. (2017). Sosiolinguistik Yogyakarta. Yogyakarta: SABDA (Lembaga Studi Agama, Budaya dan Perdamaian).

Tri Budiasih, L. (2016). Illocution on Speech Acts of Foreign Students in Indonesian Learning. PAROLE: Journal of Linguistics and Education, 6(2), 41-48. https://doi.org/10.14710/parole.v6i2.41-48

Tutuarima, Z., Nuraeningsih, N., \& Rusiana, R. (2018). An Analysis of Speech Act Used in London Has Fallen Movie. Vision: Journal for Language and Foreign Language Learning. https://doi.org/10.21580/vjv7i23022

Zulfa, A. F. (2018). A Graduating Paper, The Types of Illocutionary Acts on the Hackerman's Utterances in Cyberbully Movie. State Islamic University Sunan Kalijaga. 